\title{
Degradation of Fungal and Actinomycete Mycelia by Agaricus bisporus
}

\author{
By T. R. FERMOR ${ }^{1 *}$ AND W. D. GRANT ${ }^{2}$ \\ ${ }^{1}$ Glasshouse Crops Research Institute, Worthing Road, Littlehampton, West Sussex BN17 6LP, UK \\ ${ }^{2}$ Cawthron Institute, PO Box 175, Nelson, New Zealand
}

(Received 26 November 1984)

Commercial wheat straw/horse manure compost used for production of the cultivated mushroom Agaricus bisporus contains a fungal and actinomycete microbial biomass of some $1.5 \%$ before inoculation with $A$. bisporus. It has been shown that these mycelia can be used by $A$. bisporus as a sole source of carbon, nitrogen and phosphorus. Mycelium of the thermophilic fungus Humicola insolens var. thermoidea, a major component of compost microbial biomass, was digested over a $28 \mathrm{~d}$ period by $A$. bisporus growing in liquid culture, as determined by light and electron microscopy. Mycelial walls of $H$. insolens var. thermoidea contained (by wt) $30 \%$ glucose, $22 \%$ glucosamine, $6-8 \%$ galactose, $2-3 \%$ mannose and traces of other sugars. Enzymes that possibly degrade fungal and actinomycete cell walls were produced by $A$. bisporus during growth on such mycelia, and activities of other extracellular enzymes involved in the decomposition of cytoplasmic contents were determined.

\section{INTRODUCTION}

The edible mushroom Agaricus bisporus is grown commercially on composted horse manure and wheat straw mixtures. During composting the straw surfaces become coated with an amorphous polysaccharide matrix in which are embedded microbial cells and debris (Eddy \& Jacobs, 1976; Atkey \& Wood, 1983) and by the end of the composting process some $1.5 \%$ of the dry weight is fungal and actinomycete mycelia (Sparling et al., 1982). These surface layers on the straw disappear during colonization of the compost by mushroom mycelium, and may thus be a nutrient source for the mushroom. Growth of $A$. bisporus on compost bacteria has been demonstrated (Fermor \& Wood, 1981). The present study shows that fungal and actinomycete mycelia can also be used by Agaricus as its sole source of carbon, nitrogen and phosphorus.

Grant et al. (1984) found that extracellular enzymes produced by $A$. bisporus lysed bacterial cell walls. The composition of the mycelial walls of Humicola insolens var. thermoidea, a major fungal component of the compost microbial biomass, has been investigated in this work in order to assay for possible wall-degrading enzymes produced by $A$. bisporus. Other extracellular enzymes probably involved in the decomposition of fungal cytoplasmic contents are also described.

\section{METHODS}

Organisms. Humicola insolens var. thermoidea (Cooney \& Emerson) comb. nov. (Ellis, 1982) was isolated by direct plating of straws from a commercial horse manure/wheat straw compost. The straw sample was taken immediately before inoculation with $A$. bisporus ('spawning') and isolations were made on malt extract agar ( $2 \%$, $w / v)$ incubated at $45^{\circ} \mathrm{C}$ for $5 \mathrm{~d}$. Four thermophilic actinomycetes that are commonly found in compost (Streptomyces thermovulgaris, Streptomyces $\mathrm{sp}$. B, Thermoactinomyces vulgaris and Saccharomonospora viridis) were isolated from a rapidly prepared non-manure, straw compost (Smith, 1983) using half-strength nutrient agar (Oxoid) incubated at $50{ }^{\circ} \mathrm{C}$ for $6 \mathrm{~d}$. Streptomyces clavuligerus and Penicillium chrysogenum were obtained as autoclaved mycelia from commercial antibiotic-producing fermentations (Beecham Pharmaceuticals). Agaricus bisporus D62l of commercial origin was used. 
Bulk culture of organisms. $H$. insolens var. thermoidea inoculum was grown overnight $\left(50^{\circ} \mathrm{C}, 150\right.$ r.p.m. $)$ in two flasks ( $250 \mathrm{ml}$ ) each containing Czapek Dox liquid medium (Oxoid; $100 \mathrm{ml}$ ). For batch culture, Czapek Dox liquid medium (201) was supplemented with yeast extract powder (Oxoid; $0.5 \mathrm{~g} \mathrm{l}^{-1}$ ) and autoclaved (103 $\mathrm{kPa}, 40 \mathrm{~min}$ ). The medium was inoculated with $H$. insolens var. thermoidea and stirred, aerated and incubated at $45^{\circ} \mathrm{C}$ for $48 \mathrm{~h}$. The fungal pellets were harvested by sieving through 'Tygan' mesh and rinsed with copious quantities of distilled water. Examination by light microscopy showed very few spores were present. The mycelium was then freezedried and finely powdered using a pestle and mortar. Mycelium for wall preparations was grown for only $7-8 \mathrm{~h}$ to ensure almost total absence of spores.

Actinomycete mycelium was produced in nutrient broth (Oxoid) shaken at 150 r.p.m. for $48 \mathrm{~h}$ at $45^{\circ} \mathrm{C}$.

Media and culture of $A$. bisporus. Basal salts medium (Treschow, 1944; see Fermor \& Wood, 1981) was used as the standard medium in determining production of transparent 'clearing' zones by $A$. bisporus in opaque solid medium containing suspended, washed and autoclaved fungal or actinomycete mycelia. The pH of these media was maintained by phosphate buffers which were added separately after autoclaving ( $103 \mathrm{kPa}, 20 \mathrm{~min})$; vitamins were added after filter sterilization (Fermor \& Wood, 1981). Plates were inoculated with A. bisporus D621 (mycelial disc, $6 \mathrm{~mm}$ diam.) and incubated at $25^{\circ} \mathrm{C}$.

In the liquid medium used to study the pattern of extracellular enzyme production by $A$. bisporus on fungal mycelium, the phosphate buffer was replaced by $0.05 \mathrm{M}$-MES buffer $\mathrm{pH} 6.0\left(100 \mathrm{ml}^{-1}\right)$, so that $H$. insolens var. thermoidea mycelium was the sole source of carbon, nitrogen and phosphorus for mushroom growth. Each flask ( $250 \mathrm{ml}$ capacity) contained Treschow's basal salts medium $(25 \mathrm{ml})$ plus powdered mycelium of $H$. insolens var. thermoidea $(250 \mathrm{mg})$ and was inoculated with $A$. bisporus D621 $(0.1 \mathrm{ml}$; prepared as described by Fermor \& Wood, $1981)$ and incubated at $25^{\circ} \mathrm{C}$. Cultures were gently hand-shaken for $1 \mathrm{~min}$ per day during incubation.

Preparation of mycelial walls of $H$. insolens var. thermoidea. Mycelium was harvested and washed with ice-cold $1 \mathrm{M}-\mathrm{NaCl}$ in $0 \cdot 1 \mathrm{M}$-Tris buffer $\mathrm{pH} 8 \cdot 0$, rather than water, to minimize clumping of walls after hyphal breakage. The mycelium was broken by shaking with Ballotini beads $(0 \cdot 10-0 \cdot 11 \mathrm{~mm}$ diam.) in a Braun Model MSK cell homogenizer, cooled with liquid $\mathrm{CO}_{2}$. Breakage was monitored by phase-contrast microscopy and was complete after $3 \mathrm{~min}$ at 4000 r.p.m. The broken hyphae were washed at least 12 times with the cold $\mathrm{NaCl} /$ buffer solution, centrifuging at $5000 \mathrm{~g}$ after each wash. When all phase-dark material had been removed, the walls were washed three times with distilled water and freeze-dried. Acid hydrolysates of these walls contained only traces of amino acids, indicating that contamination with cytoplasmic material was slight.

Wall fractionation and analysis. Walls were chemically fractionated by the procedure of Mahadevan \& Tatum (1965) into fractions I (alkali-soluble), II (acid-soluble), III (acid-insoluble, alkali-soluble) and IV (acid-and alkaliinsoluble). These fractions and whole walls were analysed qualitatively by descending paper chromatography of acid hydrolysates on Whatman no. 1 or no. $3 \mathrm{MM}$ paper in the following solvents: A, butan-1-ol/pyridine/glacial acetic acid/water $(60: 40: 3: 30$, by vol.) (for hexosamines and amino acids); and B, ethyl acetate/pyridine/water $\left(8: 2: 1\right.$, by vol.) (for neutral sugars). Neutral sugars were detected with alkaline $\mathrm{AgNO}_{3}$ (Trevelyan et al., 1950); hexosamines and amino acids with ninhydrin $(0.2 \%$ in acetone); and uronic acids with aniline-diphenylamine reagent (Dawson et al., 1969). For analysis of neutral sugars, walls were hydrolysed under $\mathrm{N}_{2}$ in $11 \cdot 25 \mathrm{M}^{-} \mathrm{H}_{2} \mathrm{SO}_{4}$ at $30{ }^{\circ} \mathrm{C}$ for $3 \mathrm{~h}$, followed by dilution to $0.43 \mathrm{M}-\mathrm{H}_{2} \mathrm{SO}_{4}$ and heating at $96-98^{\circ} \mathrm{C}$ for $4 \mathrm{~h}$, again under $\mathrm{N}_{2}$ (BartnickiGarcia, 1966). Acid was neutralized with $\mathrm{BaCO}_{3}$. For glucosamine analysis, hydrolysis was in $6 \mathrm{M}-\mathrm{HCl}$ at $100^{\circ} \mathrm{C}$ for $4 \mathrm{~h}$ or $6 \mathrm{~h}$ under $\mathrm{N}_{2}$. Deacidification was by repeated evaporation to dryness over $\mathrm{P}_{2} \mathrm{O}_{5}$ and $\mathrm{NaOH}$ pellets.

Glucose was determined with glucose oxidase (TEKIT 952 DM; Searle Diagnostics Inc., Chicago, USA), galactose with galactose oxidase (Roth et al., 1965), and mannose by elution of the mannose regions from paper chromatograms of hydrolysates, followed by measurement of reducing sugar (Lever, 1972). Standards and blanks were chromatographed on and eluted from the same paper. Glucosamine was determined by quantitative paper chromatography of hydrolysates and standards in solvent $\mathrm{A}$, followed by staining the dried papers with the cadmium acetate/ninhydrin mixture of Heilmann et al. (1957), elution of the spots with methanol, and colorimetry at $500 \mathrm{~nm}$. The results obtained were confirmed by hexosamine analysis by the Elson-Morgan procedure of Gatt \& Berman (1966).

The action of laminarinase (mollusc; Sigma) on fraction III was assayed in $0.05 \mathrm{M}$-sodium citrate buffer $\mathrm{pH} 5 \cdot 0$ at $37^{\circ} \mathrm{C}$, by measuring glucose released. The action of chitinase (Streptomyces; Sigma) on fraction IV was assayed after thoroughly suspending the fraction in $0.05 \mathrm{M}$-sodium citrate buffer $\mathrm{pH} 6.0$, and measuring release of reducing sugar. The $\mathrm{N}$-acetylglucosamine released was identified by co-chromatography with an authentic sample in solvent $\mathrm{A}$.

IR spectra of fraction IV and authentic chitin (crustacean shells; Sigma) were obtained on a Unican SP-200 spectrophotometer after powdering the samples with $\mathrm{KCl}$ and pressing into discs.

Enzyme assays. Centrifuged culture supernatants were assayed for extracellular enzyme activity using the techniques described by Fermor \& Wood (1981). All assays were done on at least three replicates. $\beta-N$ Acetylgalactosaminidase (EC 3.2.1.53) and $\beta$ - $N$-acetylglucosaminidase (EC 3.2.1.30) were assayed spectrophotometrically using the corresponding $p$-nitrophenyl substrates (Sigma). $\beta$ - $N$-Acetylmuramidase (lysozyme) (EC 
3.2.1.17) was assayed by measuring the decrease in optical density of a suspension of Micrococcus lysodeikticus (Sigma) at $540 \mathrm{~nm}$ in a Pye Unicam SP 30 spectrophotometer. The chitinolytic activity of supernatants was assessed by adding supernatant $(1.0 \mathrm{ml})$ to a suspension of purified chitin (Sigma; $10 \mathrm{mg} \mathrm{ml}^{-1}$ ) in $0.05 \mathrm{M}$-citrate/ phosphate buffer pH $6.6(1.0 \mathrm{ml})$ and incubating it at $25^{\circ} \mathrm{C}$ for $1 \mathrm{~h}$ (Monreal \& Reese, 1969). The reducing sugar released by chitinase activity (EC 3.2.1.14) was measured by the Nelson-Somogyi method using a standard curve for $N$-acetylglucosamine read at $500 \mathrm{~nm}$. Before assay for nucleases, supernatants were concentrated 15 - to 20-fold by ultrafiltration over a PM 10 membrane (Amicon) and then an agar diffusion technique was used (Fermor $\&$ Wood, 1981). Laccase (EC 1.10.3.2) was assayed polarographically and was used as a growth marker for $A$. bisporus (Wood \& Goodenough, 1977). To assay laminarinase activity (EC 3.2.1.6), culture supernatant ( $(0 \cdot 25 \mathrm{ml})$ was added to laminarin substrate (Calbiochem; $20 \mathrm{mg} \mathrm{ml}^{-1}$ in $0.25 \mathrm{ml}$ distilled water) in $0.05 \mathrm{M}$-acetate buffer $\mathrm{pH}$ $5.0(0.5 \mathrm{ml})$, and incubated for $1 \mathrm{~h}$ at $25^{\circ} \mathrm{C}$. The reducing sugars released were measured by the Nelson-Somogyi method using a standard curve for D-glucose read at $500 \mathrm{~nm}$. Lipase (EC 3.1.1.3) was assayed using a modified agar diffusion method with tributyrin as substrate. Acid, neutral and alkaline proteases were measured colorimetrically by liberation of dye from an insoluble hide powder substrate conjugated with Remazol Brilliant Blue (Rinderknect et al., 1968).

\section{RESULTS}

\section{Growth of A. bisporus on actinomycete and fungal mycelium in agar}

A. bisporus produced transparent zones in the opaque Treschow's basal salts medium (cleared zones) when the medium contained washed, autoclaved mycelial suspensions of the actinomycetes Streptomyces clavuligerus, Streptomyces thermovulgaris, Streptomyces sp. B, Saccharomonospora viridis and Thermoactinomyces vulgaris as sole carbon and nitrogen sources. Sections of agar gel taken from 'cleared zones' were stained and examined by light microscopy. They showed an almost total absence of actinomycete mycelium $(0.5-0.75 \mu \mathrm{m}$ diam.) which was easily distinguished from $A$. bisporus mycelium $(2 \cdot 5-5 \cdot 0 \mu \mathrm{m}$ diam.) by its smaller hyphal diameter. A. bisporus mycelial growth on media containing the three Streptomyces species could not be accurately measured as it was sparse and did not form a coherent mycelial front. The $A$. bisporus hyphae growing on these actinomycetes were highly branched in comparison with those hyphae growing on malt extract agar $(2 \%, \mathrm{w} / \mathrm{v})$. In contrast, $A$. bisporus mycelium growing on $T$. vulgaris and Sacch. viridis was sparse but grew in thick infrequently branched strands.

$A$. bisporus also produced 'cleared zones' in opaque media containing either $H$. insolens var. thermoidea or $P$. chrysogenum fungal mycelium. The colony radial extension rate of $A$. bisporus mycelium on these media was about $1.0 \mathrm{~mm} \mathrm{~d}^{-1}$. Examination by light microscopy of the 'cleared zones' revealed an almost total absence of non-Basidiomycete mycelium. The distance of 'cleared zones' in advance of the growing mycelial front (on media containing suspended Humicola or Penicillium mycelium) could be increased by incubating the plates in a refrigerator, which slowed hyphal growth whilst allowing extracellular enzymes to diffuse through the media.

\section{Composition of mycelial walls of $H$. insolens var. thermoidea}

The walls contained (by wt) $30 \%$ glucose, $22 \%$ glucosamine, $6-8 \%$ galactose, $2-3 \%$ mannose and traces of other sugars. Galactosamine and uronic acids were not present. Chemical fractionation of the walls yielded two main polysaccharide-containing fractions. Fraction III formed a gel with water, accounted for $15 \%$ of the original wall weight, and on acid hydrolysis produced only glucose, with small amounts of oligosaccharides. Treatment with laminarinase resulted in the release of $50 \%$ of the glucose residues as free glucose. Fraction IV was insoluble in water and accounted for $23 \%$ of the original wall. Acid hydrolysis converted this fraction to free glucosamine with traces of glucose. Treatment with chitinase released only small amounts of $\mathrm{N}$ acetylglucosamine (approx. $5 \%$ of total glucosamine present) in solution. However, the IR spectrum of this fraction was virtually indistinguishable from that of an authentic chitin sample. Fraction I from the Mahadevan \& Tatum (1965) procedure contained $10 \%$ of the wall weight as poly- or oligosaccharide(s) of glucose, galactose and mannose (approx. ratio $6: 3: 1$ ). Fraction II accounted for almost $50 \%$ of the wall weight as free glucose, galactose and mannose (approx. ratio $3: 1: 1)$ and traces of glucosamine, these being acid hydrolysis products of the polysaccharides present in the other fractions. 


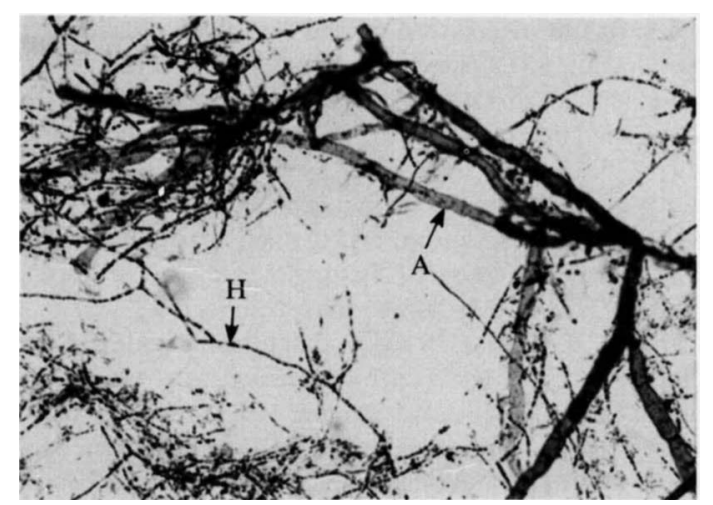

Fig. 1. Agaricus bisporus (A) growing on mycelium of Humicola insolens var. thermoidea (H) as sole carbon, nitrogen and phosphorus sources in liquid culture (14 d after inoculation). Magnification $\times 400$.

Table 1. Enzyme activities produced by A. bisporus growing on mycelium of $H$. insolens var. thermoidea

\begin{tabular}{|c|c|c|c|c|c|c|c|}
\hline Enzyme & $\begin{array}{l}\text { Possible } \\
\text { substrate }\end{array}$ & $\begin{array}{l}\quad \text { Time }(\mathrm{d}) \ldots 0 \\
\text { pH of } \\
\text { supernatant } \ldots .5 .5\end{array}$ & $\begin{array}{c}7 \\
5 \cdot 4\end{array}$ & $\begin{array}{l}14 \\
5 \cdot 6\end{array}$ & $\begin{array}{l}21 \\
5 \cdot 7\end{array}$ & $\begin{array}{l}28 \\
5 \cdot 8\end{array}$ & $\begin{array}{l}56^{*} \\
5 \cdot 7\end{array}$ \\
\hline $\begin{array}{l}\beta-N \text {-Acetylgalactos- } \\
\text { aminidase } \dagger\end{array}$ & Cell wall & ND & ND & ND & ND & ND & 0.19 \\
\hline DNAase & DNA & - & - & - & - & - & + \\
\hline Laccase $\ddagger$ & $\begin{array}{c}\text { (Growth } \\
\text { marker) }\end{array}$ & ND & $0 \cdot 010$ & 0.031 & $0 \cdot 120$ & 0.084 & $0 \cdot 199$ \\
\hline $\begin{array}{l}\text { Laminarinase (endo- } \\
1,3-\beta \text {-D-glucanase) } \S\end{array}$ & $\begin{array}{l}\text { Cell wall } \\
\text { glucans }\end{array}$ & - & ND & ND & ND & $22 \cdot 0$ & $19 \cdot 0$ \\
\hline Lipase & Lipids & - & ND & ND & + & + & + \\
\hline Protease $\|$ & Protein & & & & & & \\
\hline Acid pH 3.6 & & - & ND & ND & $2 \cdot 11$ & $3 \cdot 33$ & $10 \cdot 70$ \\
\hline Neutral pH 7.0 & & - & ND & ND & $7 \cdot 16$ & $9 \cdot 11$ & $25 \cdot 68$ \\
\hline Alkaline pH 9.1 & & - & ND & ND & 6.79 & $7 \cdot 18$ & $24 \cdot 02$ \\
\hline RNAase & RNA & - & - & - & - & - & + \\
\hline $\begin{array}{l}- \text {, Not determined; } \\
\text { " All Humicola myc } \\
\dagger \text { Expressed as } \mu \mathrm{mo} \\
\text { † Expressed as } \mu \mathrm{mo} \\
\S \text { Expressed as } \mu \mathrm{g} \\
\mid \text { Expressed as } \mu \mathrm{g} \mathrm{R}\end{array}$ & $\begin{array}{l}\text { ND, not dete } \\
\text { lium degrad } \\
\text { nitropheno } \\
\mathrm{O}_{2} \text { released } \\
\text { lucing suga } \\
\text { mazol Brill }\end{array}$ & $\begin{array}{l}+, \text { enzyme present. } \\
\text { observed by light } \\
\text { sed (ml supernatant } \\
\text { supernatant })^{-1} \mathrm{~min}^{-} \\
\text {supernatant) })^{-1} \text { min } \\
\text { lue solubilized }(\mathrm{ml} \mathrm{s}\end{array}$ & $\begin{array}{l}\text { roscopy. } \\
\min ^{-1} \text {. }\end{array}$ & & & & \\
\hline
\end{tabular}

\section{Growth of $A$. bisporus on mycelium of $H$. insolens var. thermoidea in liquid medium}

After an early lag phase $A$. bisporus grew on mycelium of $H$. insolens var. themoidea as sole carbon, nitrogen and phosphorus sources, as shown by light microscopy and by the increase in activity of the enzyme laccase which is proportional to mycelial dry weight (Wood, 1979) (Fig. 1, Table 1). Degradation of mycelium of $H$. insolens var. thermoidea (Fig. 1) was confirmed by electron microscopy. Culture supernatants were assayed for extracellular enzymes (Table 1), which could account for the degradation of fungal wall polymers and intracellular lipids, nucleic acids and proteins. Highest enzyme activities were recorded after $21 \mathrm{~d}$ and by $28 \mathrm{~d}$ no visible mycelium of $H$. insolens var. thermoidea remained in the cultures. Activities of $\beta-N$ acetylglucosaminidase and $\beta$ - $N$-acetylmuramidase, which were induced in the presence of bacterial cell walls (Fermor \& Wood, 1981; Grant et al., 1984), were not detected in the presence of mycelium of $H$. insolens var. thermoidea. Moreover, chitinase activity was not detected by the assay techniques used. Nucleases were only detected after the supernatants were concentrated 15- to 20 -fold. The $\mathrm{pH}$ of the culture supernatants remained constant throughout the $56 \mathrm{~d}$ duration of the experiments (Table 1). 


\section{DISCUSSION}

Fungal and actinomycete mycelia represent a considerable potential nutritional resource for Agaricus bisporus growing in compost. The total microbial biomass in a horse manure and wheat straw compost has been estimated immediately before inoculation (spawning), by both direct counts and biochemical methods, as $9.2 \mathrm{mg} \mathrm{C}$ (g dry wt compost) ${ }^{-1}$ (Sparling et al., 1982); this represents approx. $2 \%$ of compost dry weight assuming that microbial biomass contains $50 \%$ carbon. The ratio of fungal and actinomycete to bacterial biomass in this compost was $2 \cdot 8: 1$. However, the relative proportions of fungal to actinomycete mycelia in compost is unknown.

The maximum contribution of the microbial biomass to mushroom biomass has been calculated as less than $10 \%$ (Sparling et al., 1982). This suggests that $A$. bisporus probably obtains the bulk of its carbon nutrition from straw. However, the nitrogen content of microbial biomass is high, and since micro-organisms will also concentrate minerals during composting, the biomass could act as a concentrated source of nitrogen and minerals. Streptomyces clavuligerus mycelium, for example, contained on average $11 \%$ nitrogen by dry weight and Penicillium chrysogenum contained $3.4 \%$ nitrogen (Jenkinson, 1981), although the mineral content of organisms will vary depending on growth conditions (Van Veen \& Paul, 1979).

Compost is cooled to $25^{\circ} \mathrm{C}$ before inoculation with mushroom mycelium and so a large proportion of the thermophilic microflora will be near or below its minimum growth temperature. The thermophilic actinomycetes Saccharomonospora viridis, Streptomyces thermovulgaris and Thermoactinomyces vulgaris all have a minimum temperature for growth of $27^{\circ} \mathrm{C}$; they will be in a static state at $25^{\circ} \mathrm{C}$, with the mycelial structure remaining intact assuming no autolysis occurs. A significant fraction of the nutrient content of the compost may thus be present within the microflora and available only to micro-organisms which possess the enzyme systems needed to degrade them. Atkey \& Wood (1983) observed that actinomycete hyphae, often showing considerable cellular breakdown, were frequently found in close association with A. bisporus hyphae, particularly towards the end of cropping. Humicola insolens var. thermoidea has a minimum temperature for growth of $23^{\circ} \mathrm{C}$ (Cooney \& Emerson, 1964) and yet is isolated only occasionally from spent compost at the end of cropping.

The actinomycetes tested represent three of the four major actinomycete cell wall types as recognized by Gottlieb (1974). All contain $N$-acetylmuramyl- $\beta$-1,4- $N$-acetylglucosamine linkages in their peptidoglycans, and it is therefore possible that the $\beta$ - $N$-acetylmuramidase secreted by $A$. bisporus which degrades walls of Bacillus subtilis (Grant et al., 1984) would also be capable of attacking these actinomycete walls.

Investigation of the wall composition of mycelium of $H$. insolens var. thermoidea has shown that it is probably of the common chitin-glucan type V (Bartnicki-Garcia, 1968). The glucan contains $\beta(1 \rightarrow 3)$ linkages, since it was extensively degraded by commercial laminarinase. Laminarinase activity was detected in supernatants of $A$. bisporus growing on $H$. insolens var. thermoidea (Table 1). The failure to detect chitinase activity in such supernatants could be explained if the enzyme was produced but was adsorbed on to the insoluble mycelial substrate. This type of enzyme adsorption phenomenon was noted by Manning \& Wood (1983) who found that the extracellular endocellulase activity of $A$. bisporus in culture filtrates was inversely related to cellulose concentration in the culture and that free cellulase could be bound to cellulose. Similarly, Grant et al. (1984) showed that the extracellular $\beta$ - $N$-acetylmuramidase activity of $A$. bisporus cultures was considerably higher in cultures containing a lower concentration of bacterial cell walls.

The carbon chain lengths of fatty acids in compost resemble those often found in the hyphae and spores of thermophilic fungi. Micro-organisms, particularly fungi, are probably the only source of polyunsaturated fats in compost and these are important nutrients for $A$. bisporus (Wain, 1981). Although the lipid component of $H$. insolens var. thermoidea was not analysed in the present study, lipase activity of A. bisporus was measurable after $21 \mathrm{~d}$ growth on Humicola mycelium.

Attempts to improve compost productivity by inoculation of thermophilic fungi into mushroom compost after completion of composting has had little beneficial effect, as an adequate natural fungal population is already present (Ross \& Harris, 1983). Increased 
knowledge of the nutritional requirements of the mushroom should result in advances in the ability to manipulate $\boldsymbol{A}$. bisporus for crop production. It is conceivable that a formulated supplement of microbial origin could act as a slowly released nutrient to increase mushroom yield during the later stages of cropping.

We thank Dr I. Normansell, Beecham Pharmaceuticals, Worthing, UK, for providing organisms. We also thank Dr D. Wood for criticism and encouragement, and Sarah Molyneux and Barbara Prosser for skilful technical assistance.

\section{REFERENCES}

AtKeY, P. T. \& WoOD, D. A. (1983). An electron microscope study of wheat straw composted as a substrate for the cultivation of the edible mushroom (Agaricus bisporus). Journal of Applied Bacteriology 55, 293-304.

BARTNICKI-GARCIA, S. (1966). Chemistry of hyphal walls of Phytophthora. Journal of General Microbiology 42, 57-69.

BARTNICKI-GarCIA, S. (1968). Cell wall chemistry, morphogenesis, and taxonomy of fungi. Annual Retiew of Microbiology 22, 87-108.

COONey, D. G. \& Emerson, R. (1964). Thermophilic Fungi. An Account of Their Biology, Activities and Classification. San Francisco: W. H. Freeman.

Dawson, R. M. C., Elliott, D. C., Elliott, W. H. \& JONES, K. M. (1969). Data for Biochemical Research, 2nd edn, p. 542. Oxford: Clarendon Press.

EDDY, B. P. \& JACOBS, L. (1976). Mushroom compost as a source of food for Agaricus bisporus. Mushroom Journal 38, 56-59.

ElLIS, D. H. (1982). Ultrastructure of thermophilic fungi. V. Conidial ontogeny in Humicola grisea var. thermoidea and $H$. insolens. Transactions of the British Mycological Society 78, 129-139

FERMOR, T. R. \& WOOD, D. A. (1981). Degradation of bacteria by Agaricus bisporus and other fungi. Journal of General Microbiology 126, 377-387.

GatT, R. \& Berman, E. R. (1966). A rapid procedure for the estimation of amino sugars on a micro scale. Analytical Biochemistry 15, 167-171.

GotTlieb, D. (1974). Actinomycetales. In Bergey's Manual of Determinative Bacteriology, 8th edn, p. 658. Edited by R. E. Buchanan \& N. E. Gibbons. Baltimore: Williams \& Wilkins.

Grant, W. D., Fermor, T. R. \& Wood, D. A. (1984). Production of bacteriolytic enzymes and degradation of bacterial cell walls during growth of Agaricus bisporus on Bacillus subtilis. Journal of General Microbiology 130, 761-769.

Heilmann, J., Barrollier, J. \& Watzke, E. (1957). Determinations of amino acids on paper chromatograms. Zeitschrift für physiologische Chemie 309, 219220.

JENKINSON, D. S. (1981). The fate of plant and animal residues in soil. In The Chemistry of Soil Processes, pp. 505-561. Edited by D. J. Greenland \& M. H. B. Hayes. Chichester: John Wiley.

LEVER, M. (1972). A new reaction for colorimetric determination of carbohydrates. Analytical Biochemistry 47, 273-279.

Mahadevan, P. R. \& Tatum, E. L. (1965). Relation- ship of the major constituents of the Neurospora crassa cell wall to wild-type and colonial morphology. Journal of Bacteriology 90, 1073-1081.

Manning, K. \& Wood, D. A. (1983). Production and regulation of extracellular endocellulase by Agaricus bisporus. Journal of General Microbiology 129, 1839 1847.

Monreal, J. \& ReESE, E. T. (1969). The chitinase of Serratia marcescens. Canadian Journal of Microbiology 15, 689-696.

Rinderknect, H., Geokas, M. C., Silverman, P. \& Haverback, B. J. (1968). A new ultrasensitive method for the determination of proteolytic activity. Clinica chimica acta 21, 197-203.

Ross, R. C. \& HarRIS, P. J. (1983). The significance of thermophilic fungi in mushroom compost preparation. Scientia Horticulturae 20, 61-70.

Roth, H., Segal, S. \& Bertoli, D. (1965). The quantitative determination of galactose - an enzymic method using galactose oxidase, with applications to blood and other biological fluids. Analytical Biochemistry 10, 32-52.

Smith, J. F. (1983). The formulation of mixtures suitable for economic, short-duration mushroom composts. Scientia Horticulturae 19, 65-78.

SPARling, G. P., Fermor, T. R. \& WOOD, D. A. (1982). Measurement of the microbial biomass in composted wheat straw, and the possible contribution of the biomass to the nutrition of Agaricus bisporus. Soil Biology and Biochemistry 14, 609-611.

TRESCHOW, C. (1944). Nutrition of the cultivated mushroom. Dansk botanisk Arkiv 11, 1-180.

Trevelyan, W. E., Procter, D. P. \& Harrison, J. S. (1950). Detection of sugars on paper chromatograms. Nature, London 166, 444-445.

VAN VeEn, J. A. \& Paul, E. A. (1979). Conversion of biovolume measurements of soil organisms, grown under various moisture tensions, to biomass and their nutrient content. Applied and Environmental Microbiology 37, 686-692.

$\mathrm{W}_{\mathrm{AIN}}$, D. I. (1981). Investigation of the nutrition of the mushroom Agaricus bisporus (Lang) Sing. in compost. PhD thesis, University of Bath, UK.

WooD, D. A. (1979). A method for estimating biomass of $A$. bisporus in a solid substrate, compost wheat straw. Biotechnology Letters 1, 255-260.

Wood, D. A. \& Goodenough, P. W. (1977). Fruiting of Agaricus bisporus. Changes in extracellular enzyme activities during growth and fruiting. Archives of Microbiology 114, 161-165. 